\title{
Peningkatan Keterampilan Menulis Resensi \\ Buku Ilmiah pada Mahasiswa Melalui \\ Program Satu Semester Satu Resensi (Tuter Tensi)
}

\author{
Hamidulloh Ibda ${ }^{1 凶}$ \\ Sekolah Tinggi Agama Islam Nahdlatul Ulama (STAINU) Temanggung \\ h.ibdaganteng@stainutmg.ac.id
}

\begin{abstract}
The skills of writing scientific book reviews on students can be improved through the application of the program "One Semester One Review" (Tuter Tensi). This study aims to improve the skills of writing scientific book reviews for students published in the mass media. The research uses action research methods with four components, namely planning, action, observation, and reflection. From the results of research conducted on 89 Islamic Education (PAI) students and Madrasah Ibtidaiyah Teacher Education (PGMI) STAINU Temanggung experienced a significant increase in scientific book review skills. In action 1, significant results were obtained. The writing aspect of the title of the review was 70 students (78 percent) completed, aspects of writing names and affiliation as many as 87 students (97 percent) completed, writing a book biodata with completeness 76 students (85 percent), writing content as many as 73 students (82 percent) complete, aspects of writing shortcomings and advantages of books as many as 78 students (87 percent) completed, and the use of General Indonesian Spelling Guidelines (PUEBI) as many as 75 students (84 percent) completed. In action 2, the aspect of writing the review title was 85 students (95 percent) completed, writing the name of the authorization and affiliation as many as 89 students (100 percent) completed, writing a book biodata with completeness 86 students (96 percent), writing 86 student reviews (96 percent) complete, aspects of writing shortcomings and strengths of books 88 students (98 percent) completed, and the use of General Indonesian Spelling Guidelines (PUEBI) as many as 84 students (94 percent) completed.
\end{abstract}

Keywords: writing skills, book review, 'one semester one review' program.

Abstrak : Keterampilan menulis resensi buku ilmiah pada mahasiswa dapat ditingkatkan melalui penerapan program "Satu Semester Satu Resensi" (Tuter Tensi). Penelitian ini bertujuan meningkatkan keterampilan menulis resensi buku ilmiah pada mahasiswa yang dimuat di media massa. Penelitian menggunakan metode action research (penelitian tindakan) dengan empat komponen, yaitu perencanaan, tindakan, pengamatan, dan refleksi. Dari hasil penelitian yang

Sitasi Artikel:

Ibda, H. (2020). Peningkatan Keterampilan Menulis Resensi Buku Ilmiah pada Mahasiswa Melalui Program Satu Semester Satu Resensi (TUTER TENSI). Disastra: Jurnal Pendidikan Bahasa dan Sastra Indonesia, 2(1), 1-13. doi:http://dx.doi.org/10.29300/disastra.v2i1.1998 
dilakukan pada 89 mahasiswa Pendidikan Agama Islam (PAI) dan Pendidikan Guru Madrasah Ibtidaiyah (PGMI) STAINU Temanggung mengalami peningkatan signifikan pada keterampilan menulis resensi buku ilmiah. Pada tindakan 1, didapatkan hasil signifikan. Aspek menulis judul resensi sebanyak 70 mahasiswa (78 persen) tuntas, aspek menulis nama peresensi dan afiliasi sebanyak 87 mahasiswa (97 persen) tuntas, menulis biodata buku dengan ketuntasan 76 mahasiswa ( 85 persen), menulis isi resensi sebanyak 73 mahasiswa (82 persen) tuntas, aspek menulis kekurangan dan kelebihan buku sebanyak 78 mahasiswa (87 persen) tuntas, dan penggunaan Pedoman Umum Ejaan Bahasa Indonesia (PUEBI) sebanyak 75 mahasiswa (84 persen) tuntas. Pada tindakan 2, aspek menulis judul resensi sebanyak 85 mahasiswa (95 persen) tuntas, menulis nama peresensi dan afiliasi sebanyak 89 mahasiswa (100 persen) tuntas, menulis biodata buku dengan ketuntasan 86 mahasiswa (96 persen), menulis isi resensi 86 mahasiswa (96 persen) tuntas, aspek menulis kekurangan dan kelebihan buku 88 mahasiswa (98 persen) tuntas, dan penggunaan Pedoman Umum Ejaan Bahasa Indonesia (PUEBI) sebanyak 84 mahasiswa (94 persen) tuntas.

Kata Kunci : keterampilan menulis, resensi buku, progam satu semester satu resensi

\section{Pendahuluan}

Dalam teori caturtunggal

keterampilan berbahasa, menulis menjadi salah satu keterampilan produktif yang diajarkan pada mahasiswa di perguruan tinggi, baik berupa karya ilmiah, karya jurnalistik bahkan karya sastra. Untuk meningkatkan keterampilan menulis pada mahasiswa, dibutuhkan sebuah program, model, atau strategi yang mendorong mereka berpikir kritis dan kontekstual berbasis praktik.

Pembelajaran kontekstual terbukti mampu mendorong pelajar dalam menulis, meningkatkan motivasi berpartisipasi secara aktif dalam kelas menulis, serta membantu pelajar mengembangkan tulisan mereka (Gunawan, 2012:10). Salah satu bentuk pembelajaran kontekstual adalah dengan mewajibkan mahasiswa menulis resensi di media massa, baik siber atau cetak secara terstruktur, sistematis ${ }_{2}$ dan masif.

Menulis merupakan kegiatan wajib bagi mahasiswa terutama menulis berbentuk karya ilmiah. Menulis karya ilmiah dapat berupa bagian dari tugas kuliah yang diberikan dosen pada mahasiswa, baik dalam bentuk esai, review, artikel ilmiah, makalah, atau karya ilmiah (skripsi, tesis, dan disertasi) sebagai salah syarat untuk memperoleh gelar sarjana, magister, atau doktor. Melalui kegiatan menulis karya ilmiah, mahasiswa diharapkan dapat mengomunikasikan informasi, pengetahuan baru, gagasan, kajian, dan hasil penelitian (Persadha, 2016:1). Salah satu mata kuliah yang mendorong peningkatan keterampilan menulis pada mahasiswa adalah Bahasa Indonesia. Dari riset yang ada, lahirnya kesadaran bahwa menulis merupakan keterampilan sangat penting untuk dikuasai adalah ketika mengikuti mata kuliah Bahasa Indonesia khususnya pada materi menulis karya ilmiah (Thalia, 2012:178).

Menulis sebagai keterampilan produktif diakui lebih susah dari keterampilan reseptif seperti membaca dan menyimak. Lebih rinci, menulis merupakan kegiatan menurunkan lambang atau melukiskan lambang-lambang grafik yang menggambarkan suatu bahasa yang dipahami orang lain, sehingga mereka dapat 
membaca lambang-lambang grafik itu sebagai representasi satu kesatuan dari ekspresi bahasa (Tarigan, 2008:21). Keterampilan menulis merupakan sebuah keterampilan untuk mengekspresikan ide, konsep, gagasan, atau perasaan, dengan menggunakan bahasa tulis dengan tujuan dapat dipahami pembaca sesuai isi tulisan yang dimaksud (Ibda, 2019:113).

Keterampilan menulis dapat disebut sebagai keterampilan yang paling sulit bagi pelajar. Akan tetapi kurikulum mengharuskan pelajar terampil mengusai keterampilan menulis tanpa mengabaikan keterampilan yang lain (Efnawarty, 2019:82). Keterampilan menulis untuk pemula berawal dari mekanika (huruf kapital di awal kalimat dan untuk nama), tata bahasa, kosakata dan ejaan (Peterson, 2003:ix-xi).

Keterampilan menulis seseorang bukanlah suatu proses yang otomatis didapat sejak lahir, melainkan diperoleh melalui proses belajar, serta diperkuat dengan latihan yang cukup dan teratur (Andra, 2019:79). Bagi mahasiswa semester awal dapat disebut sebagai penulis pemula. Menulis merupakan keterampilan yang dapat dikuasi semua orang dengan cara pembelajaran dan pembiasaan, khususnya bagi insan akademik.

Dalam dunia akademik, selain skripsi, tesis, dan disertasi, banyak sekali jenis karya ilmiah. Selain artikel ilmiah, ada esai ilmiah, makalah, dan resensi buku. Resensi atau teks ulasan merupakan teks berisi sebuah kritik, evaluasi, atau review pada karya cipta intelektual. Jenis tulisan ini memiliki tujuan untuk memberikan kritikan, hasil evaluasi, atas suatu karya ilmiah, buku, atau karya seni. Resensi atau teks ulasan merupakan tulisan berisi menimbang atau menilai sebuah karya yang dikarang atau dicipta orang lain (Pardiyono, 2007:313).

Menulis resensi adalah salah satu usaha untuk mengenalkan buku pada orang lain yang belum membaca, sehingga setelah membaca resensi orang lain akan tergerak hatinya untuk membaca karya orang lain tersebut. Resensi buku adalah salah satu cara membudidayakan minat baca terhadap buku baru. Untuk meresensi buku, pertamatama peresensi harus membaca buku itu sampai selesai dan memahami isinya (Soffalina, 2010:2). Sehingga, peresensi dapat menimbang aspek kelebihan dan kekurangan buku yang diresensi.

Menulis resensi merupakan kemampuan menuangkan pendapat tentang buku orang lain yang telah dibaca. Resensi diklasifikasikan menjadi tiga bidang garapan, yakni (1) buku fiksi dan nonfiksi, (2) pementasan seni, seperti film, kaset, tari, drama, serta sinetron, dan (3) pameran seni, baik seni patung atau lukisan (Samad, 1997, p. 1). Namun yang lebih sering dilakukan mahasiswa di perguruan tinggi adalah menulis resensi buku nonfiksi atau buku ilmiah yang integral dengan keterampilan membaca buku di perguruan tinggi.

Sebuah penelitian pada seratus mahasiswa di Bandung, menyatakan keterampilan menulis menempati posisi pertama dalam memenuhi kebutuhan pembelajaran Bahasa Indonesia di kampus, dan perkuliahan Bahasa Indonesia selama ini belum berperan maksimal dalam meningkatkan penguasaan keterampilan menulis ilmiah. Berdasarkan penelitian ini, kemampuan menulis menjadi prioritas untuk dikuasai mahasiswa (Chaedar; Alwasilah, 2004:113). Untuk itu, dibutuhkan program strategis yang dapat meningkatkan keterampilan menulis resensi pada 
mahasiswa. Sebab, menulis resensi tidak semudah menulis opini atau karya ilmiah yang lain.

Resensi atau teks ulasan memiliki tingkat kesulitan tinggi. Pasalnya, resensi adalah teks yang dihasilkan dari sebuah analisis mendalam terhadap satu hal dengan melibatkan berbagai hal sebagai pertimbangan, sehingga menghadirkan penilaian yang adil dan rasional dari teks itu dan teks ulasan memiliki struktur penulisan baku. Teks itu memuat tanggapan, tinjauan, dan analisis terhadap buku, literatur, dan karya sastra, baik cerpen, novel, film, drama dan lainnya (Supriyanti, 2017:25). Menulis teks ulasan harus fokus dan sesuai dengan pertanyaan pada ulasan. Kemudian peresensi dapat mengekstrak informasi yang berhubungan dengan pertanyaan-pertanyaan ulasan, dan menjalinnya bersama menjadi jawaban. Tujuannya, agar pembaca dapat melihat mengapa peresensi menyebutkan karya itu dan apa yang dipikirkan peresensi (Wray, 2011:44).

Sistematika penulisan resensi, review, ulasan atau timbangan buku disusun dengan urutan judul resensi, nama peresensi dan afiliasi, biodata buku (judul buku, ISBN, cetakan dan tahun terbit, tebal, penulis, editor, penerbit, dan harga), isi resensi, kekurangan dan kelebihan buku (Ibda, 2019:143). Pendapat lain menyebut keterampilan menulis resensi dimulai dari judul resensi sebagai salah satu hal penting sebelum melanjutkan pada unsur-unsur berikutnya. Setelah judul resensi, unsur selanjutnya terdiri atas data buku, pendahuluan, isi pernyataan, dan penutup (Samad, 1997:7). Pendapat lain menyebut unsur-unsur dalam resensi selain judul resensi, yaitu data buku, pendahuluan, isi pernyataan, dan penutup (Wardani, 2012:10).

Dari riset yang ada, peningkatan keterampilan menulis resensi buku dapat meningkat dengan metode yang relevan sesuai kebutuhan pelajar (Supriyanti, 2017:xiv). Salah satu bentuknya melalui penugasan menulis resensi dalam bentuk satu semester satu resensi untuk satu mahasiswa.

Sebagai keterampilan produktif, berbicara dan menulis membutuhkan pendekatan, model, metode ${ }_{2}$ atau program yang dapat meningkatkan dua keterampilan ini. Seperti contoh riset penerapan strategi "Satu Mahasiswa Satu Video" (Tua Tou) yang dapat meningkatkan keterampilan berbicara tembang macapat dalam pekuliahan Bahasa Daerah Pendidikan Dasar pada aspek intonasi, artikulasi, volume, dan cengkok lagu (Wijanarko, 2019:39). Begitu juga dengan riset yang mengkaji peningkatan keterampilan menulis artikel ilmiah pada mahasiswa STAINU Temanggung, didapatkan hasil dengan penerapan program satu "Semester Satu Satu Buku" (Tuter Tuku) yang dapat meningkatkan keterampilan menulis artikel ilmiah pada mahasiswa. Bentuknya berupa satu kelas mahasiswa memiliki satu buku karya mereka sendiri yang diterbitkan penerbit (Ibda; Wahyuningsih, 2019:10).

Dari penjelasan di atas, dapat disimpulkan keterampilan menulis resensi mahasiswa merupakan keterampilan yang susah jika tidak diajarkan dan diprogramkan secara strategis. Selain menulis judul resensi, mahasiswa juga harus dapat menulis judul resensi, nama peresensi dan afiliasi, biodata buku (judul buku, ISBN, cetakan dan tahun terbit, tebal, penulis, editor, penerbit, dan harga), isi resensi, kekurangan 
dan kelebihan buku. Selain itu, menulis di media massa khususnya resensi juga harus taat dan melaksanakan penggunaan Pedoman Umum Ejaan Bahasa Indonesia (PUEBI). Oleh karena itu, penulis melakukan penelitian pada mahasiswa Program Studi Pendidikan Agama Islam (PAI) dan Pendidikan Guru Madrasah Ibtidaiyah (PGMI) STAINU Temanggung pada mata kuliah Bahasa Indonesia Lanjutan tahun ajaran 2018-2019 di semester genap.

\section{Metode Penelitian}

Desain penelitian ini menggunakan metode action research (penelitian tindakan). Proses pelaksanaan penelitian tindakan ini didesain model dari Kemmis dan Mc. Taggart yang perangkatnya terdiri atas empat komponen, yaitu perencanaan, tindakan, pengamatan, dan refleksi (Iskandar, 2011:28). Jenis penelitian tindakan yang digunakan adalah action research experimental, yang intinya penelitian diselenggarakan dengan berupaya menerapkan berbagai teknik atau strategi secara efektif dan efisien di dalam suatu kegiatan (Rahman, 2018:5).

Tujuan dari penelitian ini untuk meningkatan keterampilan menulis resensi buku ilmiah pada mahasiswa Prodi PAI dan PGMI STAINU Temanggung. Masalah spesifik yang dikaji adalah peningkatan keterampilan menulis resensi buku ilmiah dan penerapan program "Satu Semester Satu Resensi" (Tuter Tensi) dalam perkuliahan Bahasa Indonesia Lanjutan.

Penulis dalam penelitian tindakan ini melakukan perencanaan, tindakan, dan refleksi tentang peningkatan keterampilan menulis resensi buku ilmiah pada mahasiswa STAINU Temanggung melalui tindakan berupa "Satu Semester Satu
Resensi" (Tuter Tensi) yang dilakukan. Peneliti terlibat secara langsung dalam pelaksanaan program tersebut dari perencanaan tindakan sampai dengan refleksi. Dalam penelitian ini, responden diambil dari mahasiswa STAINU Temanggung yang terdiri atas Prodi PAI dan PGMI yang berjumlah lima rombel/kelas dengan total 89 mahasiswa. Setiap mahasiswa diwajibkan menulis satu resensi buku ilmiah. Kemudian, dari resensi itu dibedah di kelas, dan setelah diberi komentar dari mahasiswa lain dan dosen, maka dikirim ke media massa khususnya media massa siber.

Dalam penelitian tindakan ini, instrumen data dikumpulkan melalui observasi terstruktur selama pertemuan perkuliahan Bahasa Indonesia Lanjutan sejak tahap perencanaan sampai tahap refleksi. Selain dengan observasi peneliti juga menggunakan angket atau lembar tes untuk memperkuat data optimalisasi penguasaan menulis resensi buku ilmiah pada mahasiswa.

Pengumpulan data peningkatan keterampilan menulis didasarkan pada ketuntasan mahasiswa dalam resensi buku yang dimuat di media massa. Mulai dari aspek keterampilan mahasiswa menulis judul resensi, nama peresensi dan afiliasi, biodata buku (judul buku, ISBN, cetakan dan tahun terbit, tebal, penulis, editor, penerbit, dan harga), isi resensi, kekurangan dan kelebihan buku, serta menggunakaan Pedoman Umum Ejaan Bahasa Indonesia (PUEBI). Data penelitian ini berupa resensi buku karya mahasiswa yang merupakan salah satu tugas akhir mata kuliah Bahasa Indonesia Lanjutan pada tahun ajaran 20182019. 
Untuk menghitung dan menganalisis ketuntasan mahasiswa dalam menulis resensi buku, peneliti menggunakan rumus:

$$
P=\frac{\sum \text { Mahasiswatuntas }}{\sum \text { Mahasiswa }} \times 100 \%
$$

Keterangan:

P: Ketuntasan

$\sum$ : Jumlah mahasiswa

Sebelum perencanaan, peneliti melakukan observasi dan menyebar angket tentang keterampilan mahasiswa dalam menulis judul resensi, nama peresensi dan afiliasi, biodata buku (judul buku, ISBN, cetakan dan tahun terbit, tebal, penulis, editor, penerbit, dan harga), isi resensi, kekurangan dan kelebihan buku, serta penggunaan PUEBI. Langkah selanjutnya, melakukan pendataan terkait jumlah mahasiswa yang tuntas dan tidak tuntas sesuai keterampilan di atas.

Tindakan berikutnya berupa edukasi tentang keterampilan menulis resensi meliputi keterampilan menulis judul resensi, nama peresensi dan afiliasi, biodata buku (judul buku, ISBN, cetakan dan tahun terbit, tebal, penulis, editor, penerbit, dan harga), isi resensi, kekurangan dan kelebihan buku, serta penggunaan PUEBI. Penelitian dilakukan pada semester genap tahun ajaran 2018-2019 yang dimulai bulan Januari 2019 sampai Juni 2019.

\section{Hasil dan Pembahasan}

Hasil penelitian ini dibagi atas tiga pembahasan. Pertama adalah lemahnya keterampilan menulis resensi buku ilmiah. Kedua, peningkatan keterampilan menulis resensi melalui program "Satu Semester Satu Resensi” (Tuter Tensi) yang berisi hasil tindakan pertama dan tindakan kedua.
Ketiga, peluang dan hambatan dari penerapan program ini.

\section{Rendahnya Keterampilan Menulis Resensi Buku Ilmiah}

Berdasarkan hasil observasi dan angket yang disebarkan pada 89 mahasiswa Prodi PAI dan PGMI STAINU Temanggung, didapat informasi tentang keterampilan menulis resensi buku ilmiah dengan tabel di bawah ini.

Tabel 1: Keterampilan Menulis Resensi Buku Ilmiah Sebelum Tindakan

\begin{tabular}{|l|c|c|}
\hline \multicolumn{1}{|c|}{ Materi } & $\begin{array}{c}\text { Jumlah } \\
\text { Mahasiswa } \\
\text { yang } \\
\text { Tuntas }\end{array}$ & $\begin{array}{c}\text { Persentase } \\
\text { Ketuntasan }\end{array}$ \\
\hline $\begin{array}{l}\text { Keterampilan menulis } \\
\text { judul resensi }\end{array}$ & 50 & 56 Persen \\
\hline $\begin{array}{l}\text { Menulis nama } \\
\text { peresensi dan afiliasi }\end{array}$ & 85 & 95 Persen \\
\hline $\begin{array}{l}\text { Menulis biodata buku } \\
\text { judul buku, ISBN, } \\
\text { cetakan dan tahun } \\
\text { terbit, tebal, penulis, } \\
\text { editor, penerbit, dan } \\
\text { harga) }\end{array}$ & 65 & 73 Persen \\
\hline Menulis isi resensi & 53 & 59 Persen \\
\hline $\begin{array}{l}\text { Menulis kekurangan } \\
\text { dan kelebihan buku }\end{array}$ & 45 & 50 Persen \\
\hline $\begin{array}{l}\text { Penggunaan Pedoman } \\
\text { Umum Ejaan Bahasa } \\
\text { Indonesia (PUEBI) }\end{array}$ & 40 & 44 Persen \\
\hline
\end{tabular}

Sumber: Hasil angket sebelum tindakan

Berdasarkan observasi dan angket tentang menulis resensi buku ilmiah pada Tabel 1, keterampilan menulis resensi buku ilmiah pada mahasiswa Prodi PAI dan PGMI STAINU Temanggung masih belum memadai atau lemah. Dari 89 mahasiswa, mereka masih kebingungan dalam menulis resensi secara utuh. Pada aspek menulis judul resensi dengan ketuntasan 50 mahasiswa (56 persen), menulis nama peresensi dan afiliasi 85 mahasiswa (95 persen), menulis biodata buku (judul buku, ISBN, cetakan dan tahun terbit, tebal, 
penulis, editor, penerbit, dan harga) dengan ketuntasan 65 mahasiswa (73 persen), menulis isi resensi dengan ketuntasan 53 mahasiswa (59 persen), menulis kekurangan dan kelebihan buku dengan ketuntasan 45 mahasiswa (50 persen), dan menggunakaan PUEBI dengan ketuntasan 40 mahasiswa (44 persen).

Dari data ini, aspek yang paling mudah adalah keterampilan menulis nama peresensi dan afiliasi. Akan tetapi, itupun belum tuntas sampai seratus persen, karena mahasiswa kurang teliti. Sedangkan aspek lainnya masih jauh di bawah 75 persen dari total mahasiswa.

\section{Peningkatan Keterampilan Menulis Resensi melalui Program "Satu Semester Satu Resensi" (Tuter Tensi)}

Program Satu Semester Satu Resensi (Tuter Tensi) ini merupakan program menulis resensi buku ilmiah yang diterapkan pada perkuliahan Bahasa Indonesia Lanjutan yang berorientasi pada produk resensi yang dimuat di media massa. Setiap mahasiswa Prodi PAI dan PGMI STAINU Temanggung diwajibkan meresensi buku sesuai dengan disiplin ilmunya masingmasing. Untuk mahasiswa $\mathrm{PAI}_{2}$ meresensi buku berjudul Sejarah dan Legenda Desa di Temanggung, Magelang dan Semarang dan Tradisi-tradisi Islam Nusantara Perspektif Filsafat dan Ilmu Pengetahuan. Sedangkan mahasiswa PGMI meresensi buku Problematika Anak MI/SD Zaman Now dan Solusinya.

Dalam rangka untuk meningkatkan keterampilan menulis resensi buku ilmiah melalui program Tuter Tensi ini, peneliti melakukan langkah tindakan dengan dimulai dari perencanaan, tindakan, pengamatan, dan refleksi sebagai berikut.

\section{Hasil Tindakan 1 \\ Tahap Perencanaan}

Peneliti pada tahap ini merencanakan kegiatan training penulisan resensi buku ilmiah di setiap kelas berdasarkan data hasil angket yang menyimpulkan bahwa, keterampilan menulis resensi pada mahasiswa belum memadai. Peneliti bertugas sebagai pemateri utama dengan mengintegrasikan pada mata kuliah Bahasa Indonesia Lanjutan ${ }_{2}$ yaitu pada materi keterampilan menulis karya ilmiah. Peneliti merencanakan program "Satu Semester Satu Resensi” (Tuter Tensi).

Peneliti menyiapkan materi training penulisan resensi tentang keterampilan mahasiswa dalam menulis judul resensi, nama peresensi dan afiliasi, biodata buku (judul buku, ISBN, cetakan dan tahun terbit, tebal, penulis, editor, penerbit, dan harga), isi resensi, kekurangan dan kelebihan buku, serta penggunaan PUEBI.

\section{Tahap Tindakan}

Peneliti bersama mahasiswa pada tahap ini melakukan training penulisan resensi buku ilmiah di masing-masing kelas. Materinya dimulai dari teknik menulis judul resensi, nama peresensi dan afiliasi, biodata buku (judul buku, ISBN, cetakan dan tahun terbit, tebal, penulis, editor, penerbit, dan harga), isi resensi, kekurangan dan kelebihan buku, serta penggunaan PUEBI. Selain itu, mahasiswa juga dikenalkan jenisjenis media massa baik cetak atau siber yang menerima tulisan resensi buku dari masyarakat umum.

Tindakan selanjutnya, mahasiswa menulis resensi buku yang disepakati di setiap kelas, kemudian dikirim ke email peneliti untuk dikumpulkan dan dikaji bersama. Setelah terkumpul, naskah resensi 
dikaji bersama di kelas untuk diberi kritikan dan masukan untuk penyempurnaan. Jika naskah resensi masih tidak sesuai pedoman yang disampaikan saat training, maka mahasiswa diwajibkan melalukan revisi sampai sempurna. Selanjutnya naskah dikembalikan kepada mahasiswa untuk dikirimkan ke media massa. Namun pada tindakan pertama ini, mahasiswa belum berani mengirimkan naskahnya ke media massa.

Pada akhir proses training penulisan resensi, mahasiswa diberi angket dengan tujuan untuk mengetahui tingkat keberhasilan mahasiswa dalam proses training penulisan resensi buku ilmiah dalam program "Satu Semester Satu Resensi" ini yang telah dilakukan. Adapun data hasil penelitian pada tahap tindakan setelah training penulisan resensi buku ilmiah sebagai berikut_:

Tabel 2: Keterampilan Menulis Resensi Buku Ilmiah Setelah Tindakan 1

\begin{tabular}{|l|c|c|}
\hline \multicolumn{1}{|c|}{ Materi } & $\begin{array}{c}\text { Jumlah } \\
\text { Mahasiswa } \\
\text { yang } \\
\text { Tuntas }\end{array}$ & $\begin{array}{c}\text { Persentase } \\
\text { Ketuntasan }\end{array}$ \\
\hline $\begin{array}{l}\text { Keterampilan menulis } \\
\text { judul resensi }\end{array}$ & 70 & 78 Persen \\
\hline $\begin{array}{l}\text { Menulis nama } \\
\text { peresensi dan afiliasi }\end{array}$ & 87 & 97 Persen \\
\hline $\begin{array}{l}\text { Menulis biodata buku } \\
\text { judul buku, ISBN, } \\
\text { cetakan dan tahun } \\
\text { terbit, tebal, penulis, } \\
\text { editor, penerbit, dan } \\
\text { harga) }\end{array}$ & 76 & 85 Persen \\
\hline Menulis isi resensi & 73 & 82 Persen \\
\hline $\begin{array}{l}\text { Menulis kekurangan } \\
\text { dan kelebihan buku }\end{array}$ & 78 & 87 Persen \\
\hline $\begin{array}{l}\text { Penggunaan Pedoman } \\
\text { Umum Ejaan Bahasa } \\
\text { Indonesia (PUEBI) }\end{array}$ & 75 & 84 Persen \\
\hline
\end{tabular}

Sumber: Hasil angket setelah dilakukan training penulisan resensi buku ilmiah tahap tindakan 1
Dari tahap tindakan, didapatkan data peningkatan keterampilan menulis resensi buku ilmiah pada 89 mahasiswa, didapatkan hasil pada aspek menulis judul resensi sebanyak 70 mahasiswa (78 persen), aspek menulis nama peresensi dan afiliasi sebanyak 87 mahasiswa (97 persen), menulis biodata buku (judul buku, ISBN, cetakan dan tahun terbit, tebal, penulis, editor, penerbit, dan harga) dengan ketuntasan 76 mahasiswa (85 persen), menulis isi resensi sebanyak 73 mahasiswa (82 persen), aspek menulis kekurangan dan kelebihan buku sebanyak 78 mahasiswa (87 persen), dan penggunaan Pedoman Umum Ejaan Bahasa Indonesia (PUEBI) sebanyak 75 mahasiswa (84 persen) tuntas

\section{Tahap Pengamatan}

Tahap pengamatan dilaksanakan bersama dengan pelaksaaan training penulisan resensi buku ilmiah sampai tahap diskusi, evaluasi, dan revisi. Peneliti mengamati seluruh kegiatan mahasiswa tentang pemahaman mereka terhadap materi training menulis resensi buku ilmiah. Program "Satu Semester Satu Resensi" ini dilakukan mahasiswa dengan berbagai respon, ada yang langsung paham, ada yang perlu pendampingan, dan banyak yang masih melakukan duplikasi atau mencontoh hasil resensi temannya. Peneliti melakukan penguatan pemahaman kepada semua mahasiswa melalui koordinator kelas yang bertugas mendampingi mahasiswa lain untuk menyelesaikan kesulitan selama proses menulis resensi buku ilmiah yang ditugaskan pada masing-masing mahasiswa.

\section{Tahap Refleksi}

Pada tahap ini peneliti melakukan refleksi dari kegiatan awal sampai akhir 
yang dapat disimpulkan ke dalam beberapa hal. Pertama, training penulisan resensi buku ilmiah berdampak positif terhadap pemahaman mahasiswa tentang teknik menulis judul resensi, nama peresensi dan afiliasi, biodata buku (judul buku, ISBN, cetakan dan tahun terbit, tebal, penulis, editor, penerbit, dan harga), isi resensi, kekurangan dan kelebihan buku, serta penggunaan PUEBI. Kedua, program "Satu Semester Satu Resensi" ini dapat meningkatkan keterampilan mahasiswa dalam menulis resensi buku ilmiah sesuai hasil angket. Meskipun pada tahap ini mahasiswa belum berani mengirim naskah di media massa, namun sudah ada peningkatan keterampilan menulis resensi pada masing-masing aspek.

\section{Hasil Tindakan 2}

\section{Tahap Perencanaan}

Pada tahap ini, apa yang direncanakan peneliti pada intinya sama seperti tindakan pertama. Peneliti menyiapkan materi dan melakukan penguatan khususnya pada keterampilan yang masih belum tuntas di atas 75 persen. Mulai dari aspek teknik menulis judul resensi, nama peresensi dan afiliasi, biodata buku (judul buku, ISBN, cetakan dan tahun terbit, tebal, penulis, editor, penerbit, dan harga), isi resensi, kekurangan dan kelebihan buku, serta penggunaan PUEBI.

Selain itu, yang membedakan tindakan kedua ini adalah peneliti menjalin kerjasama dengan jurnalis yang mengisi kegiatan training tersebut khususnya mengenal media massa siber yang menerima tulisan berupa resensi buku. Mahasiswa diberi alamat surel media massa dan teknik mengirim naskah resensi beserta lampiran apa saja yang harus dikirimkan ke redaksi media massa.

\section{Tahap Tindakan}

Pada tahap ini, peneliti melakukan tindakan training penulisan resensi buku ilmiah bersama-sama mahasiswa. Pada tahap tindakan ini, peneliti mengundang pemateri dari unsur praktisi, yaitu jurnalis media massa yang menjelaskan materi tentang judul resensi, nama peresensi dan afiliasi, biodata buku (judul buku, ISBN, cetakan dan tahun terbit, tebal, penulis, editor, penerbit, dan harga), isi resensi, kekurangan dan kelebihan buku, serta penggunaan PUEBI. Pemateri dari unsur jurnalis memberikan trik dan tips menulis dan mengirim naskah resensi di media massa. Pemateri dari unsur jurnalis juga menyampaikan berkas-berkas yang harus dilampirkan dalam mengirim naskah resensi di media massa. Mulai dari naskah resensi dengan format doc/rtf, biodata penulis, foto sampul, foto/scan KTP.

Setelah itu, mahasiswa memperbaiki hasil naskah resensi yang ditulis dan didiskusikan pada tindakan pertama. Setelah itu, mahasiswa mengirim naskah tersebut ke surel media massa yang dituju. Setelah pengiriman, mahasiswa menunggu sampai pemuatan maksimal satu bulan.

Setelah akhir proses training penulisan resensi buku ilmiah dan setelah naskah resensi dimuat di media massa, mahasiswa diberi angket dengan tujuan untuk mengetahui tingkat keberhasilan mahasiswa dalam proses training penulisan resensi buku ilmiah dalam program "Satu Semester Satu Resensi" ini yang telah dilakukan. Adapun data hasil penelitian pada tahap tindakan 2 setelah training 
penulisan resensi buku ilmiah dan naskah dimuat di media massa sebagai berikut.

Tabel 3: Keterampilan Menulis Resensi Buku Ilmiah Setelah Tindakan 2

\begin{tabular}{|c|c|c|}
\hline Materi & $\begin{array}{c}\text { Jumlah } \\
\text { Mahasiswa } \\
\text { yang } \\
\text { Tuntas }\end{array}$ & $\begin{array}{l}\text { Persentase } \\
\text { Ketuntasan }\end{array}$ \\
\hline $\begin{array}{l}\text { Keterampilan menulis } \\
\text { judul resensi }\end{array}$ & 85 & 95 Persen \\
\hline $\begin{array}{l}\text { Menulis nama } \\
\text { peresensi dan afiliasi }\end{array}$ & 89 & 100 Persen \\
\hline $\begin{array}{l}\text { Menulis biodata buku } \\
\text { (judul buku, ISBN, } \\
\text { cetakan dan tahun } \\
\text { terbit, tebal, penulis, } \\
\text { editor, penerbit, dan } \\
\text { harga) }\end{array}$ & 86 & 96 Persen \\
\hline Menulis isi resensi & 86 & 96 Persen \\
\hline $\begin{array}{l}\text { Menulis kekurangan } \\
\text { dan kelebihan buku }\end{array}$ & 88 & 98 Persen \\
\hline $\begin{array}{l}\text { Penggunaan Pedoman } \\
\text { Umum Ejaan Bahasa } \\
\text { Indonesia (PUEBI) }\end{array}$ & 84 & 94 Persen \\
\hline
\end{tabular}

Sumber: Hasil angket setelah dilakukan training penulisan resensi buku ilmiah tahap tindakan 2

Dari tahap tindakan kedua ini, setelah mahasiswa mengirim naskah resensi dan dimuat di media massa didapatkan data peningkatan keterampilan menulis resensi buku ilmiah pada 89 mahasiswa. Didapatkan hasil pada aspek menulis judul resensi sebanyak 85 mahasiswa (95 persen), menulis nama peresensi dan afiliasi sebanyak 89 mahasiswa (100 persen), menulis biodata buku (judul buku, ISBN, cetakan dan tahun terbit, tebal, penulis, editor, penerbit, dan harga) dengan ketuntasan 86 mahasiswa (96 persen), menulis isi resensi sebanyak 86 mahasiswa (96 persen), aspek menulis kekurangan dan kelebihan buku sebanyak 88 mahasiswa (98 persen), dan penggunaan Pedoman Umum
Ejaan Bahasa Indonesia (PUEBI) sebanyak 84 mahasiswa (94 persen) tuntas.

\section{Tahap Pengamatan}

Pada tahap pengamatan ini dilaksanakan bersama dengan pelaksaaan training penulisan resensi buku ilmiah sampai tahap diskusi, evaluasi, revisi sampai dengan pemuatan naskah resensi mahasiswa di media massa. Peneliti mengamati seluruh kegiatan mahasiswa tentang pemahaman mereka pada materi training menulis resensi buku ilmiah sampai pengiriman dan pemuatan di media massa.

Program "Satu Semester Satu Resensi" di sini dapat meningkatkan keterampilan menulis resensi buku ilmiah dengan adanya bantuan pemateri dari unsur praktisi. Terbukti semua naskah resensi buku ilmiah karya mahasiswa dapat dikirim dan dimuat di media massa siber. Alasan pengiriman di media massa siber karena sesuai perkembangan zaman, mudah diakses, dan dijangkau semua orang di mana saja berada.

Selain melalui koordinator kelas, peneliti melibatkan unsur jurnalis yang bertugas mendampingi mahasiswa untuk menyelesaikan kesulitan selama proses menulis resensi buku ilmiah yang ditugaskan pada masing hingga dimuat di media massa.

\section{Tahap Refleksi}

Pada tahap refleksi ini, peneliti melakukan refleksi dari kegiatan awal sampai akhir pada tindakan kedua yang dapat disimpulkan ke dalam beberapa aspek. Pertama, training penulisan resensi buku ilmiah berdampak positif terhadap pemahaman mahasiswa tentang teknik menulis judul resensi, nama peresensi dan 
afiliasi, biodata buku (judul buku, ISBN, cetakan dan tahun terbit, tebal, penulis, editor, penerbit, dan harga), isi resensi, kekurangan dan kelebihan buku, serta penggunaan PUEBI. Kedua, program "Satu Semester Satu Resensi" ini dapat meningkatkan keterampilan mahasiswa dalam menulis resensi buku ilmiah sesuai hasil angket dan pemuatan naskah resensi di media massa. Beberapa media massa yang memuat naskah resensi buku ilmiah kiriman mahasiswa mulai dari Tabayuna.com, Harianguru.com, Hariantemanggung.com, dan Harianjateng.com.

\section{Hambatan dan Peluang}

Dalam penerapan program "Satu Semester Satu Resensi" (Tuter Tensi) ini ada hambatan dan peluang yang peneliti temukan, baik dari aspek internal maupun eksternal. Untuk hambatan internal dan eksternal, pertama masih minimnya budaya membaca buku ilmiah, menulis ilmiah, meneliti, dan berpikir ilmiah pada mahasiswa. Kedua, kesulitan mahasiswa dalam menentukan angle (sudut pandang) pada suatu buku, sehingga mahasiswa lemah dalam judul resensi. Ketiga, lemahnya pengetahuan mahasiswa tentang resensi buku.

Keempat, minimnya pemahaman mahasiswa pada media massa, baik cetak atau siber yang menerima kiriman naskah resensi dari masyarakat. Kelima, lemahnya keberanian mahasiswa dalam menulis kekurangan buku, karena kebanyakan hanya memuji atau menulis kelebihan buku saja. Keenam, pemilihan diksi dan penggunaan bahasa yang masih kacau dan belum sesuai dengan Pedoman Umum Ejaan Bahasa Indonesia (PUEBI) sesuai Permendikbud Nomor 50 Tahun 2015 tentang Pedoman
Umum Ejaan Bahasa Indonesia maupun KBBI V (daring) di kbbi.kemdikbud.go.id. Ketujuh, minimnya keberanian mahasiswa mengirim naskah resensi ke media massa.

Sedangkan peluangnya, baik dari aspek internal atau eksternal, pertama, adanya kesadaran mahasiswa untuk menulis resensi sebagai bagian dari karya ilmiah di perguruan tinggi. Kedua, respon positif dari mahasiswa karena diajarkan cara menulis resensi di media massa. Ketiga, terbukanya akses mengirim naskah resensi di media massa. Keempat, tersedianya aplikasi KBBI daring (kbbi.kemdikbud.go.id) sebagai wahana untuk mengecek sesuai PUEBI. Kelima, dimuatnya naskah resensi mahasiswa di media siber Tabayuna.com, Harianguru.com, Hariantemanggung.com, dan Harianjateng.com. Keenam, adanya sinergi dengan jurnalis yang memberi materi dan pengalaman baru tentang karya jurnalistik, media massa, khususnya materi tentang resensi buku ilmiah yang dimuat di media massa. Ketujuh, termotivasinya dosen lain di luar mata kuliah Bahasa Indonesia untuk melaksanakan program "Satu Semester Satu Resensi" pada mahasiswa karena berbasis produk dan dimuat di media massa.

\section{Simpulan}

Berdasarkan hasil penelitian dan pembahasan, ada beberapa simpulan. Keterampilan menulis resensi buku ilmiah pada mahasiswa belum memadai sebelum diberi materi atau tindakan berupa training. Mulai dari aspek menulis judul resensi, nama peresensi dan afiliasi, biodata buku (judul buku, ISBN, cetakan dan tahun terbit, tebal, penulis, editor, penerbit, dan harga), isi resensi, kekurangan dan kelebihan buku, serta penggunaan PUEBI. Penerapan 


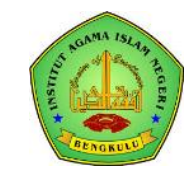

program "Satu Semester Satu Resensi" (Tuter Tensi) dapat meningkatkan keterampilan menulis resensi buku pada 89 mahasiswa Prodi PAI dan PGMI STAINU Temanggung. Mulai dari menulis judul resensi, nama peresensi dan afiliasi, biodata buku, isi resensi, kekurangan dan kelebihan buku, serta penggunaan PUEBI pada tindakan 1 dan tindakan 2.

Pada tindakan 1, didapatkan hasil signifikan. Aspek menulis judul resensi sebanyak 70 mahasiswa (78 persen) tuntas, aspek menulis nama peresensi dan afiliasi sebanyak 87 mahasiswa (97 persen) tuntas, menulis biodata buku dengan ketuntasan 76 mahasiswa (85 persen), menulis isi resensi sebanyak 73 mahasiswa ( 82 persen) tuntas, aspek menulis kekurangan dan kelebihan buku sebanyak 78 mahasiswa (87 persen) tuntas, dan penggunaan Pedoman Umum Ejaan Bahasa Indonesia (PUEBI) sebanyak 75 mahasiswa (84 persen) tuntas. Pada tindakan 2, pada aspek menulis judul resensi sebanyak 85 mahasiswa (95 persen) tuntas, menulis nama peresensi dan afiliasi sebanyak 89 mahasiswa (100 persen) tuntas, menulis biodata buku dengan ketuntasan 86 mahasiswa (96 persen), menulis isi resensi sebanyak 86 mahasiswa (96 persen) tuntas, aspek menulis kekurangan dan kelebihan buku sebanyak 88 mahasiswa (98 persen) tuntas, dan penggunaan Pedoman Umum Ejaan Bahasa Indonesia (PUEBI) sebanyak 84 mahasiswa (94 persen) tuntas.

Dalam penerapan program "Satu Semester Satu Resensi" buku ini ada tujuh faktor hambatan dari internal dan eksternal. Selain itu juga ada tujuh peluang dari aspek internal dan eksternal.

\section{Daftar Pustaka}

A. Chaedar dan Alwasilah. (2004).
Perspektif Pendidikan Bahasa Inggris di Indonesia dalam Konteks Persaingan Global. Bandung: Andira.

Andra, V. (2019). Korelasi Antara Kemampuan Membaca Kritis dengan Kemampuan Menulis Argumentasi Siswa Kelas VII A Smp Negeri 9 Kota Bengkulu. Disastra: Jurnal Pendidikan Bahasa Dan Sastra Indonesia, 1(1), 77-86.

https://doi.org/http://dx.doi.org/10.293

00/disastra.v1i1.1904

Efnawarty. (2019). Peningkatan

Kemampuan Menulis Teks Diskusi dengan Menggunakan Model Kooperatif Learning Tipe Debat pada Siswa Kelas VIII H Smp Negeri 1 Rejang Lebong. Disastra: Jurnal Pendidikan Bahasa Dan Sastra Indonesia, $\quad$ 1(2), 78-89. https://doi.org/http://dx.doi.org/10.293 00/disastra.v1i2.1903

Gunawan, I. S. E. E. M. H. (2012). Contextual Teaching And Learning Approach To Teaching Writing. Indonesian Journal of Applied Linguistics, 2, 10-22. https://doi.org/http://dx.doi.org/10.175 09/ijal.v2i1.70

Ibda, Hamidulloh. (2019). Bahasa Indonesia

Tingkat Lanjut untuk Mahasiswa (Dilengkapi Caturtunggal Keterampilan Berbahasa) (1st ed.). Semarang: CV. Pilar Nusantara.

Ibda, Hamidulloh; Wahyuningsih, Effi. (2019). Improving Students' Skill of Writing Scientific Articles Through 'One Semester One Book' Writing Program. International Journal of English Education and Linguistics, 1, 10-23. Retrieved from https://ejournal.unuja.ac.id/index.php/ij 
Volume 2, Nomor 1, Januari 2020 ISSN 2655-3031 (P), 2655-7851 (O)

ee/article/view/483/0.

Iskandar. (2011). Penelitian Tindakan Kelas

(1st ed.). Jakarta: Gaung Persada.

Pardiyono. (2007). Pasti Bisa!! Teaching Genre Based Writing (1st ed.). Yogyakarta: Andi.

Persadha, D. A. K. (2016). Studi Kompetensi Kemampuan Menulis di Kalangan Mahasiswa. MUADDIB: Studi Kependidikan Dan Keislaman, 6, $1-20$.

https://doi.org/http://dx.doi.org/10.242

69/muaddib.v6i1.159.

Peterson, P. W. (2003). Developing Writing Writing Skills: Practice Book for ESL Beginning/Intermediate Level (2nd ed.). Washington, DC: Materials Development and Review Branch The English Language Programs Division United States Information Agency.

Rahman, T. (2018). Aplikasi Model-model Pembelajaran dalam Penelitian Tindakan Kelas. (K. Saifuddin, Ed.) (1st ed.). Semarang: CV. Pilar Nusantara.

Samad, D. (1997). Dasar-dasar Meresensi Buku (1st ed.). Jakarta: PT. Gramedia Widiasarana Indonesia.

Soffalina, Y. (2010). Peningkatan Keterampilan Menulis Resensi Buku dengan Menggunakan Model Pembelajaran Kooperatif Tipe Jigsaw pada Siswa Kelas XI IPA-1 SMA Muhammadiyah 1 Surakarta Tahun Ajaran 2009/ 2010. Universitas Muhammadiyah Surakarta. Retrieved from http://eprints.ums.ac.id/8439/

Supriyanti, S. (2017). Peningkatan Kemampuan Menulis Ulasan Buku Fiksi Menggunakan Metode Student Team Achievement Division (STAD) Siswa Kelas XI IPS 2 SMA Negeri 4
Mataram Tahun Pembelajaran 20162017. Universitas Mataram. Retrieved from

http://eprints.unram.ac.id/3033/1/SUD

SUPRIYANTI_E1C013047.pdf.

Tarigan, H. G. (2008). Menulis Sebagai Suatu Keterampilan Berbahasa. Bandung: Angkasa.

Thalia, L. E. R. N. (2012). Upaya Meningkatkan Kemampuan Menulisis Imiah Mahasiswa S1 Fisioterapi UMS dengan Metode Kolaborasi Pada Tahun Akademik 2012/2013. Jurnal Penelitian Humaniora, 13, 178-189. Retrieved from https://publikasiilmiah.ums.ac.id/handl e/11617/4833

Wardani, P. K. (2012). Hubungan Minat Menulis Resensi dengan Kemampuan Menulis Resensi Siswa Kelas XI SMA Widya Gama Malang. Universitas Negeri Malang. Retrieved from http://jurnalonline.um.ac.id/data/artikel/artikelE4B 28BEA6B9F3AA2F0461E3523886590 .pdf

Wijanarko, A. G. (2019). Strategi Tua Tuo Untuk Meningkatkan Ketrampilan Berbicara (Tembang Macapat). Jurnal Iqra': Kajian Ilmu Pendidikan, 4, 8 41.

https://doi.org/https://doi.org/10.25217/ ji.v4i1.479

Wray, M. W. A. (2011). Critical Reading and Writing for Postgraduates (2nd ed.). London: SAGE Publications Ltd. 